\title{
Paper Versus School Information Management Systems: Governing the Figurations of Mediatized Schools in England and Germany
}

\author{
Andreas Breiter and Arne Hendrik Rube
}

\subsection{INTRODUCTION}

Teaching and learning are the core processes of schools, constituting their frame of relevance, in other words 'good education'. But, with changing educational governance as well as a changing media environment, administrative and strategic processes increasingly gain importance. This is because of the introduction of neo-liberal concepts such as new public management and other systems for accountability that are emerging on a global scale. The international competitiveness of the

The original version of the book was revised: Incorrect reference and corresponding reference citation have been corrected. The erratum to the book is available at https://doi.org/10.1007/978-3-319-65584-0_19
A. Breiter $(\square) \cdot$ A.H. Ruhe
ZeMKI, Centre for Media, Communication and Information
Research, University of Bremen, Bremen, Germany
e-mail: abreiter@uni-bremen.de

A.H. Ruhe

e-mail: ahruhe@ifib.de

(C) The Author(s) 2018

A. Hepp et al. (eds.), Communicative Figurations,

Transforming Communications - Studies in Cross-Media Research, https://doi.org/10.1007/978-3-319-65584-0_13 
education system has become an important playground for education politics (Grek 2009; Martens et al. 2010; Selwyn 2011, 2013). With the availability of large-scale databases, school data on pupils, staff, budget or infrastructure receive more attention. Schools can be compared with 'key performance indicators' locally, nationally and internationally. In this combination, these databases build 'infrastructures of accountability' (Anagnostopoulos et al. 2013) on different levels of educational governance. While pedagogical research on information and communication technology (ICT) integration in the core processes of schools is manifold, documented in handbooks and shows significant differences between and within countries, there is a lack of empirical results on communicative practices in school organization and the related managerial processes. What is more, the media ensemble related to these practices is only partially known-in contrast to the well-researched practices in classrooms. In particular, the widespread implementation of school management information systems in England and the lack thereof in Germany opens up the question as to whether and, if so, how governance structures shape the way schools are constituted as organizations and constructed as communicative figurations. The school's media ensemble is a moulding force for changes in communicative practices within the actor constellation of schools, among staff, students and administrators as well as in contact with parents. It is accompanied and reinforced by new public management procedures to reorganize school governance and control, which in turn require management information systems for decision-making as new parts of the media ensemble. This chapter will describe theoretically the frame of relevance in relation to educational governance and compare empirically media ensemble and communicative practices of secondary schools in England and Germany.

\subsection{Schools as Communicative Figurations}

The general concept of communicative figurations as introduced in this book allows us to draw attention to under-researched areas of educational institutions. In particular, the media-related communicative practices for organizing the school have shown a significant change during the last decade. This relates to communication between students, teachers, school management, parents and the administration. Mediatization in the life of children and young people (Livingstone 2009) as well as the impact on teaching and learning (e.g. Voogt and Knezek 2008; 
Spector et al. 2014) have been widely researched. International comparative studies on ICT integration in both elementary and secondary schools show significant changes of teaching and learning practices (e.g. SITES: Kozma 2003a; Plomp et al. 2003) and student skills (e.g. ICILS: Fraillon et al. 2014). Additionally, they highlight country-specific differences in access and use of ICT, and learning outcomes. The role of ICT in this change process and its integration in institutionalized learning environments such as schools is under constant political discussion, ranging from high expectation attached to the next technological wave (Mayer-Schönberger and Cukier 2013) to profound scepticism (e.g. Cuban 2001; Ball 2007; Selwyn 2011). Compared with this, there are only a few studies from an organizational perspective.

Just recently, Livingstone and Sefton-Green (2016) finished their empirical research on a school class in an English suburban secondary school. Besides the detailed reconstruction of the 'digital life' of students (grade 8), they refer to organization-specific changes which affect the media ensemble of the school and the communicative practices between core actors:

In the case of the VFS [the school, the authors], the information management system used was called SIMS, and talk of 'SIMS' figured routinely in students' and teachers' accounts of the school day. [...] Teachers entered and extracted information about any student's progress or behaviour throughout the school day via a range of computers available to them across the school. We observed that each student might attract between two and ten entries on any one day, resulting in a detailed database. (Livingstone and Sefton-Green 2016: 140)

If we regard an information management system as part of a school's media ensemble, this already indicates why a process perspective is necessary to understand transformations. In particular the relation between different actors within and outside the school and their individual media repertoire is relevant for the communicative construction of the school as a whole institution:

In the class, connections between people and places were most sought among peers (locally or online) and most avoided between home and school. [...] Parents' efforts to bridge the home-school divide by organizing learning at home were unrecognized by or even problematic for the school, while teachers' efforts to bridge that same divide using digital technologies were fragile and short-lived. (Livingstone and Sefton-Green 2016: 247) 
While integrated information management systems are less common in German schools, there is a growing number of learning management systems (LMS) which are used to exchange classroom material between students and teachers, to plan lessons or to distribute and collect homework (Avgeriou et al. 2003). Research in German schools (Karbautzki and Breiter 2011) showed that teachers used the system mainly to inform students. Instructional use was less prominent. This coincides with findings from Belgium (De Smet et al. 2012) and Switzerland (Petko and Moser 2009).

Schools are organizations that can be defined by their orientation to a shared purpose and practices (teaching, learning and administering), by a coordinated division of work or responsibility (staff, school management) and by certain rules of membership (Breiter 2001). In organizational studies, schools are often characterized as loosely coupled systems' (Weick 1976, 1982) with highly autonomous actors who work independently. March and Olsen (1986) used the 'garbage can model' to describe the cellular structure and the ambiguity of decision-making in educational institutions, as there are no exact measurable goals and an unclear hierarchy. Weick has described organizations as the 'process of organizing', referring to streams of practices, materials, actors, interests, solutions, problems and decisions (Weick 1969: 90). Organizations are neither static nor stable entities, and change according to negotiations and enactment. They are described by the practices of actors rather than by goals or objectives: 'When action is the central focus, interpretation, not choice, is the core phenomenon' (Weick et al. 2005: 409).

If we bring these concepts together, we can identify three interdependent aspects: actor constellation (students, teachers, parents, administrators, management, school board), media ensemble (SIMS, LMS, software products, internet resources) and communicative practices (from face-to-face to online communication). With respect to schools as organizations they centre around a specific frame of relevance, that is, providing 'good education' to future generations. This process-oriented view on social dynamics was described by Elias as figuration, that is, 'networks of individuals' (Elias 1978: 15). We built on this to introduce the concept of schools as communicatively constructed organizations, following the approach by Putnam and Nicotera (2009), and Taylor and van Every (2011). Schools as organizations are constructed through the communicative practices of the actors involved in their media ensemble and can, hence, be regarded as a communicative figuration. 
Borrowing from sociological research on governance (Arnott and Raab 2000; Wong 2013), we follow the framework model of educational governance (Sergiovanni et al. 1987) introduced to the German context (Altrichter 2010) and contextualize it to the role of ICT in schooling (Kozma 2003b). Assuming that the structure of the school system as well as processes of governance influence or at least frame the organizing of schools, we will focus on the core difference and communalities on the first two levels of educational governance: macro and meso. The micro level of classroom management will be excluded from analysis. Although this theoretical concept is rather static and does not fully reflect the dynamic processes of the school as a communicative figuration particular to 'deep mediatization' (see Chap. 1) across the levels, we want to take educational governance as an external framework condition in order to focus on our empirical study on the school level.

In most countries, public pressure on changing education policy enforced by international non-governmental organizations can be observed since the publication of Programme for International Student Assessment (PISA) results in the 1990s. Martens and others explained different reactions of nation states to these pressures (Martens et al. 2007; Martens et al. 2010) - from adoption of achievement tests in the national education policy, to ignoring them. This is part of a larger movement of standardization in education, output measurement and accountability (Burch 2006; Jacobsen and Young 2013). This also affects the administrative level of schools by introducing methods of 'new public management' (Pollitt and Bouckaert 2000) for budget control, benchmarks and goals to measure effectiveness. While national standards and respective testing regimes are well established in the UK, Germany has only just started. Recently, education policy in Germany changed from input orientation to output orientation with forms of educational measurement (Huber and Gördel 2006). With PISA in 2001, a gap between student achievements within Germany was reported, and this started an extensive discussion about school quality and the best 'school structure'. As a consequence, most Länder introduced central student achievement tests, which were developed by universities and special state institutions, borrowing from experiences from the UK, the USA and the Netherlands. In Germany, national standards for the core subjects were not introduced until 2005 (KMK 2005). In order to understand the frame of relevance of education governance, we will highlight some specificities of the school systems in England and Germany. The German federal government has no legal or financial 
obligations in K-12 education. The Länder are responsible for all aspects of schooling. Furthermore, all Education Acts of the Länder define a division of responsibilities between the Länder, the district and the school. This combination of centralized power at the Länder level with limited management control at the school level and the responsibility for infrastructure at the district level is unique among OECD countries (OECD 2001). The Länder department of education is responsible for general education provision, curriculum, teacher training and teacher employment, and the school district or municipality is responsible for school buildings, facility management and administration. This shared responsibility and the limited autonomy of the school and its management lead to constant budget struggles concerning ICT infrastructure. This structure leads to a systematic 'digital divide' between richer and poorer districts as well as richer and poorer schools.

The meso level of school organization has often been underestimated (Pelgrum 2001). With regard to ICT and its innovative power, the organizational perspective becomes more crucial. First of all, dealing with change is a core process in school development. This is often related to schools as learning organizations (Leithwood and Seashore 1998; Fullan 2001; Fauske and Raybold 2005). Secondly, technological innovations have to be embedded in the organizational culture to secure sustainability (Volkoff et al. 2007). Particularly in schools, this is related to funding, training and management decisions (Hodas 1996). Within the organizational setting of the school, the principal plays the central role for change processes (e.g. Blumberg and Greenfield 1986; DuFour 2002; Wissinger 2002; Green 2010). While school leadership in England is often described with attributes from management science, the role of a German principal, even in larger secondary schools, is different. English head teachers are controlled by inspections, report data to other administrators and lead their schools on a competitive market which is made partly transparent by rankings. German principals have fewer responsibilities and just receive some teaching reduction. Teachers are hired by the Länder and distributed among the schools based on certain criteria. The influence of principals on staffing depends on their region. They are responsible only for a small budget, as many decisions are made at the Länder level or on a district level. Hence, they are in a fourfold sandwich position: between staff (without directives), Länder (as control entity), parents and district (as infrastructure provider). 
This leads to our main research question. How can we describe the dynamics of the organization school as a communicative figuration and what are the interrelated aspects of educational governance? Although schools have a shared frame of relevance and a similar actor constellation, the process of organizing is rather different. We assume that communicative practices as well as differences in the media ensemble play an important role. This can only be answered on an empirical basis by comparing distinct school systems.

\subsection{Methodology}

In order to understand the internal organization of schools, we visited schools in England and Germany to gain insight into everyday practices. We base our empirical research on case studies carried out in a two-year project in two German secondary schools. ${ }^{1}$ This is used as a fixed case to subsequently collect accordant data from English schools. Secondly, we follow the sampling method of most-different design (Lijphart 1971): England as a decentralized system with high autonomy of the school but central authority through inspections and national standards; Germany as a decentralized system on the national level with Länder in charge. Within the Länder, we find a highly centralized system with no school autonomy but limited control through standards and inspections. As our special focus is on ICT for school management as part of a school's media ensemble, we conducted qualitative interviews with key stakeholders (teachers, administrators) at school management level.

The sampling and selection of schools in England was based on the assumption that we search for ICT-savvy schools. Hence, we followed two different strategies, of which the first failed. The first attempt was to use the Department for Education's School and college performance tables. ${ }^{2}$ The website offers school data for all English schools and includes all grades. 'The performance tables give information on the achievements of pupils in primary, secondary and 16-18 provision in schools and colleges, and how they compare with other schools and colleges in the local authority (LA) area and in England as a whole.' 3 Besides the school test scores (mainly key stage 2 and key stage 4 ), the tables also offer data about the financial situation of each school. One category is the ICT budget per pupil. We assumed a correlation between ICT investments, a superior ICT infrastructure within a school 
and a priority on ICT. Therefore, we tried to sample schools with the highest expenditures. This strategy was not successful. The main reason is the growing number of Academy schools in England. In 2010, the government passed the Academies Act, ${ }^{4}$ which allowed both the conversion of existing schools into Academies and the creation of new Academies (Academies Act 2010). Academies are directly funded by the government instead of the Local Education Authority (LEA). They are no longer controlled by the LEA and report less information than Community Schools (and no data on ICT budget). Colleges and Independent Schools do not have to report detailed budget statistics, either. This means that of all 5905 active Secondary Schools in 2013, 3434 did not report any information on their ICT budget. The second attempt was to search for schools which received ICT awards. One notable award is the NAACE ICT Mark. This is given to schools ' $(. .$.$) with$ good use of technology to support teaching, learning and school administration. Deservedly popular with schools wanting to demonstrate both effective and mature use of technology. Schools use this award to drive change and many are, or go on to be, outstanding. ${ }^{5}$ NAACE is a charity ICT association that supports ICT in education. ${ }^{6}$ The database included 121 Secondary Schools, which served as our sample. All schools were invited by an email to participate in our study. Six schools responded and showed interest, from which three schools were sampled (Table 13.1).

We visited all English schools for one day with two researchers. All site visits included an interview with a (vice-)principal and a head teacher. We conducted group discussions with teachers and other school staff in every school. All interviews and group discussions were recorded and transcribed. Guided tours of all schools offered the possibility to gain a deeper insight into media-related communicative practices and daily

Table 13.1 General information for English schools

\begin{tabular}{lllll}
\hline School name (anonymized) & No.pupils & Location & School form & $\mathrm{NSI}^{7}$ \\
\hline Whitefall Secondary School & 1200 & Urban & $\begin{array}{l}\text { Community school } \\
\text { (mixed gender) }\end{array}$ & $\mathrm{B}$ \\
Jaynestown Academy & 2000 & Suburban & $\begin{array}{l}\text { Converted academy } \\
\text { (mixed gender) }\end{array}$ & $\mathrm{C}$ \\
Beaumonde Academy & 1300 & Suburban & $\begin{array}{l}\text { Converted academy } \\
\text { (mixed gender) }\end{array}$ & $\mathrm{B}$ \\
\hline
\end{tabular}


Table 13.2 General information for German schools

\begin{tabular}{|c|c|c|c|}
\hline School name (anonymized) & No. pupils & Location & School form \\
\hline Waldschule & 1300 & Urban & $\begin{array}{l}\text { Gesamtschule (all tiers in secondary } \\
\text { education) }\end{array}$ \\
\hline Bergschule & 1100 & Urban & $\begin{array}{l}\text { Gesamtschule (all tiers in secondary } \\
\text { education) }\end{array}$ \\
\hline
\end{tabular}

routines. We took several pictures and notes during these tours which supplemented the interviews and transcripts.

The two German schools were visited over a period of two weeks by two researchers. As part of a larger research project, we focused on how communicative practices of teachers change owing to changing media (Welling et al. 2014). During the visits, participant observations were conducted. Wherever possible, spontaneous interviews with selected teachers took place. Additionally, group discussions with teachers and members of staff were conducted. Additionally, logfile analyses of the learning management system (Schulz and Breiter 2013) were done (Table 13.2).

In both cases, all observations, interviews and group discussions were analyzed by a qualitative research design. The recorded interviews and group discussions were transcribed. Together with notes from the observations, all data was analyzed using an inductive content analysis (Berg 2009; Flick 2014). The data is scanned for multiple iterations to ensure new categories are adapted to formerly scanned material. These categories are the basis for answering the research question.

\subsection{EMPIRICAL Findings}

During the visits to the three English and the two German schools, we gained insights into the media ensemble and the communicative practices of teachers and school administrators in everyday situations. With the help of interviews, group discussions, participant observations and school tours, it was possible to describe the school as a communicative figuration along the aspects of media ensemble and communicative practices of different actors. We start with media ensembles as they are a necessary condition to understand media-related communicative practices. 


\subsubsection{Media Ensemble}

All three English schools have an ICT infrastructure that builds the technical backbone of their media ensemble in relation to organizational practices. At Jaynestown Academy, the school provides notebooks and tablets for all teachers. A state-of-the-art network including complete wireless coverage and a state-of-the-art server architecture ensure a smooth integration into the teachers' daily routine. The Beaumonde Academy also provides laptops for teachers. A full-coverage wireless network is available and can be used by teachers, pupils and guests. Customized Google spreadsheets are used by the teachers to monitor pupils' behaviour and performance. The Whitefall Secondary School does not provide mobile devices for teachers. Instead, every classroom is equipped with a desktop computer. In England, pupils change rooms between classes, in contrast to Germany where the teachers change classrooms after each lesson. A school-wide wireless network is available and accessible by teachers and pupils. All schools provide an open-minded network policy. Teachers and pupils can bring their own devices to school and log into the school's network.

The Waldschule has a comparably good ICT infrastructure. There are several computers in every staffroom, including faculty staffrooms. Most classrooms have at least one computer. A wireless network is not available. All teachers and pupils have school-wide and own network shares. Limiting is the aspect that the school's network is older and does not offer up-to-date transfer rates. The Bergschule is also focused on ICT. Every classroom is equipped with an interactive whiteboard, which is comparable to English schools. Unfortunately, there is no full network coverage within the school, which hinders the full usage of these whiteboards (e.g. internet videos, sharing of content). There are some computers in the main staffroom. A wireless network is not available.

There are differences in the media ensemble between Germany and England as well as between the schools within each country. The crossnational differences are more important and bigger. English schools have more intense usage of ICT. This has consequences for communication practices as well as for the actor constellation.

\subsubsection{Media-Related Communicative Practices}

As a common ground, and besides all differences of mediatized communication, the English as well as the German schools show strong and stable face-to-face communicative practices. We identified strong 'forces 
of persistence' against changing established practices just because of the advent of 'new' communication technologies. Teachers in English schools as well as their German counterparts emphasized the importance of direct face-to-face contact:

(.) I am very often in my side room because my two [subject, note] colleagues are there and we exchange a lot face-to-face. That's why I'm rarely in the staff room which is not good, I force myself to go there at least every second day because it's good to see each other face to face. (teacher's group discussion 'Platane' at Waldschule)

Important communication media are the 'pigeon holes' for each teacher in the staffroom. This applies both to German and English schools. They are used for information exchange as well as for storing class material and work by pupils. Additionally, all staffrooms have pin boards with attached flyers and other information concerning everyday school life. Nevertheless, communication via pen and paper seems to be more important in German schools. One teacher mentions:

The school is governed by slips of paper (notes during participant observation at Waldschule).

Differences between Germany and England are mainly in the role of mediatized communication. The main element of the media ensemble in all three English schools is email. Email is seen as a fast and reliable form of communication which transports important information within the schools. All teachers have an email account via the school server:

A lot of (.)key information is communicated through the email system so

(.) it's in people's interest to keep up to date what's going on and check

(...) (interview vice-principal at Whitefall Secondary School)

Teachers and staff members check their emails regularly:

'(...) I think people check their email' - 'Every morning' - 'Some, yeah, every morning (.) or through the day, depending on the nature of the work they do (...)' (interview vice-principal at Whitefall Secondary School)

The high frequency of checking for new emails is made possible by the reliable ICT infrastructure. Nevertheless, direct face-to-face contact is 
still seen as one of the most important communicative practice, especially between teachers and pupils. Teachers mention the importance of a physical appearance during classes and that not all communication could be mediatized. In daily routine, they need to make use of the whole range of communication media to make sure the spread information reaches the receiver:

(...) the chances are that you're gonna need to use a range of methods, if you wanna make sure that you hit absolutely everybody (.) and that's the sort of the balance I think we have (...) (interview vice-principal at Whitefall Secondary School)

The importance of using digital and non-digital media and combining them dynamically is seen as a key competence for all members of staff:

(...) personalizing the communication, erm, so that you make sure people are getting information in a way that (.) they're gonna be able to process it and deal with it(.) (interview vice-principal at Whitefall Secondary School)

The group discussions uncovered an extensive media ensemble in English schools. The Beaumonde Academy uses social networks (Twitter, Facebook, Vine) for communication between teachers, pupils and parents. Twitter is used for direct communication between teachers and pupils (e.g. homework reminders) and for informing pupils and parents. Communication with parents is also done by recording Vine videos from school trips aboard. This communication is mostly one way, whereas Twitter and Facebook are used in a bidirectional way. The other two schools do not use social networks as intensively. They use functionalities of their SIMS and LMS to communicate with pupils and parents.

The teachers also mention the use of mobile phones. All schools have group call systems to inform parents about news or reporting absence. Attendance plays an important role in English schools as it is a key performance indicator during school inspections. While some schools ban pupils' mobile phones, all teachers are allowed to use their personal devices. Voice calls are also an important communication media between parents and teachers, especially in a case of emergency:

[We, editor's note] will use the phone, if it's (.) if it's something urgent like pretty much, certainly everybody on leadership has each other's 
mobile phone numbers (.) erm so we can contact each other if there's that kind of situation, so if it's something immediate (.) we wouldn't use email, we'd use either the phone system or the (.) or a hand-delivered note(.) (interview vice-principal at Whitefall Secondary School)

(...) we also have kind of the in-school routes and the traditional routes of a mobile phone number that parents can contact in an emergency (...) (teacher group discussion at Beaumonde Academy)

A vice-principal mentioned the difficulties of mediated communication. Surprisingly, it was not seen as a step backwards when compared with face-to-face communication. The identified challenge was about the 'correct' use of the technology. Email is not seen as the right solution for every situation. This applies especially to urgent situations:

(.) if you're teaching five classes back-to-back (.) you may not be able to check your email from nine o'clock until half past three, so if you need somebody to do something at lunchtime (.) email wouldn't be the appropriate method to get that out, because staff may not be able to check it, and staff here are pretty good about working out when email is appropriate and, well you know, and when it's not (.) (teacher group discussion at Whitefall Secondary School)

Another drawback of email is that users get 'flooded'. They are likely to overlook important information. Therefore, important information is stored and spread via the SIMS. SIMS are mainly used to manage pupils, facility management and budgeting. All relevant pupil data such as grades, classes, attendances and characteristics are stored within the systems. The system provides a link to the Office for Standards in Education, Children's Services and Skills (OFSTED) database, which sends grades and attendance statistics automatically. The Beaumonde Academy uses Google spreadsheets to exchange data with the SIMS. Two benefits of SIMS are mentioned multiple times. First, the system allows the teachers a fast and complete overview about the current status of each pupil:

(...) it (SIMS, editor's note) collects the data on the children's performance essentially (.) although we've got attendance (...) but what we're really using it for (.) is tracking how the children are coming into the school (.) and how they're progressing through their time in the school (...) (teacher group discussion at Beaumonde Academy) 
(...) then with the key assessments, they go in there, and then they feed into a current sort of predicted level for the children, their effort and behaviour would go into SIMS (.) this is sort of where we're at in our thinking $(. .$.$) (interview vice-principal at Whitefall Secondary School)$

The second-mentioned advantage is the possibility to share pupils' information with parents. They can log into the SIMS from home and see current grades, absences and other notes concerning their child. SIMS are used intensively for the communication between teachers and parents. They also offer some kind of connection between different communication media. Some notes to parents are generated by the SIMS, printed and sent via postal mail. Additionally, they can be accessed online. SIMS are also connected to the group call system in the schools to send reminders to parents.

The media-related communicative practices are different in German schools. Teachers do not have an official school email address; they have to use their private accounts. Hence, communication via email exists, but is used significantly less frequently than in England:

(...) newsletters do exist, but reach just 60 per cent of all colleagues (.) (principal interview at Waldschule)

Some teachers even refuse to use email:

(...) [the usage of email] has been a major point for controversial discussions as many teachers do not want to communicate via email (.) (teacher interview at Waldschule)

The use of private email addresses conflicts with German privacy laws and acceptable use policies. German laws prohibit the storage of individualrelated information in unsecure information technology (IT) environments, which applies to almost all commercial email providers. Besides the legal problems, this individual communicative practice is not embedded in the school's organizing practices. In both schools, the local education authority provides an LMS that helps the teachers to communicate among each other and pupils. As it is not compulsory and not embedded into the communicative practices, the usage is not very high (Schulz and Breiter 2013). This may also be owing to the limited ICT infrastructure within both schools. Combined with the lack of wireless networks, this hinders more intense usage from within the school. 
(...) there is the disadvantage that I cannot access OrgaTec [the LMS, note] directly (...) wireless coverage with an iPad would be perfect (.) (teacher group discussion 'Platane' at Bergschule)

In both cases of email and LMS, German principals cannot make the usage compulsory. This lowers their relevance within the media ensemble:

(...) email is not the main component of our official communication $(\ldots)$ mainly, because we do not have the guarantee that colleagues on the one hand get in touch with us just in time and on the other we cannot be sure that they read their emails as there are no official policies (...) (group discussion head teachers at Bergschule)

These may be the reasons that German schools still rely on paper in pigeon holes. In both schools, we were able to see the routine that every teacher, when walking into the staffroom, first looked into the pigeon holes.

To summarize the findings, we can state that German schools are governed with slips of paper while English schools are governed with SIMS.

\subsubsection{School Stakeholders and the Media Ensemble}

In the next step, we investigated the school's media ensemble and mapped it into a matrix with all relevant actors (Fig. 13.1). The left column (teacher, pupils, parents, officials) is the sender, whereas the other four columns (teacher, pupils, parents, officials) are the receivers. Owing to the visits and group discussions, we were able to restore most of the communication practices between teachers, but we still do not know about the communicative behaviour between teachers, pupils and parents and between parents and school management (Table 13.3).

As mentioned above, the main communication media are email, SIMS, LMS and file sharing. Email is the most important and used through all combinations of sender and receiver, which includes parents and officials not only as receivers, but also as senders addressing teachers. SIMS, LMS and file sharing are used more selectively. File sharing is mainly used within the schools. Both teachers and pupils have personal accounts. They are hosted on servers provided within the school or within cloud storage. Public access allows the exchanges of documents 


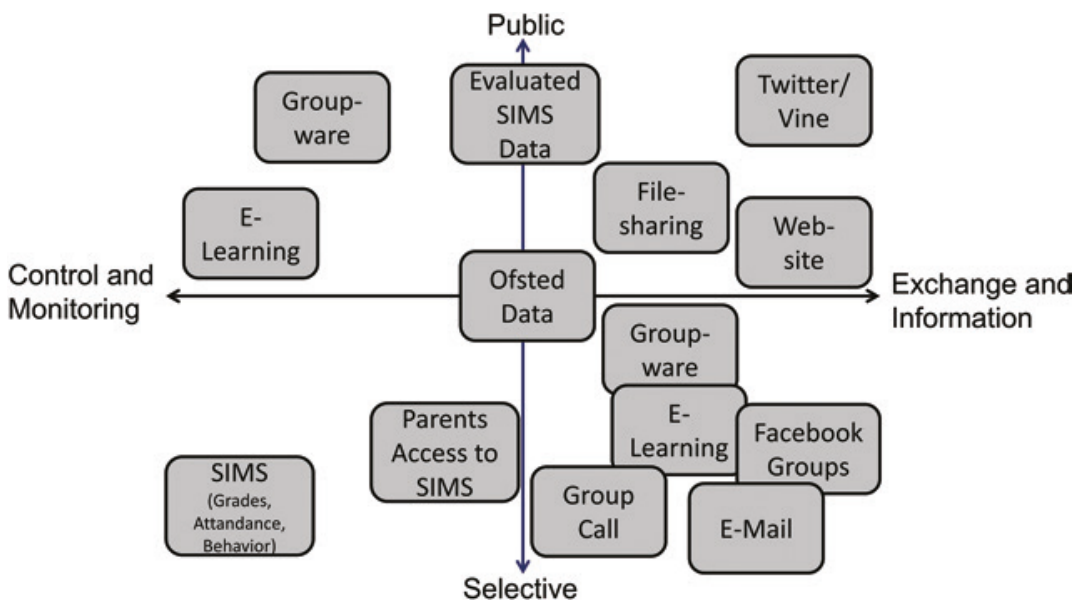

Fig. 13.1 Relation of communicative practices and media ensemble in English schools

Table 13.3 Media ensemble and actor constellation in English schools

\begin{tabular}{|c|c|c|c|c|}
\hline From/to & Teacher & Pupils & Parents & Officials \\
\hline Teacher & $\begin{array}{l}\text { SIMS } \\
\text { email } \\
\text { File Sharing } \\
\text { Pigeon Holes }\end{array}$ & $\begin{array}{l}\text { LMS } \\
\text { email } \\
\text { File Sharing } \\
\text { Social Media }\end{array}$ & $\begin{array}{l}\text { email } \\
\text { SIMS (LMS) } \\
\text { Social Media } \\
\text { Group Call } \\
\text { Pen \& Paper }\end{array}$ & $\frac{\text { SIMS }}{\text { email }}$ \\
\hline Pupils & $\begin{array}{l}\text { LMS } \\
\text { email } \\
\text { File Sharing } \\
\text { Social Media } \\
\text { Pigeon Holes }\end{array}$ & $\begin{array}{l}\text { LMS } \\
\text { File Sharing } \\
\text { email }\end{array}$ & & \\
\hline Parents & $\begin{array}{l}\text { email } \\
\text { Telephone } \\
\text { Pen \& Paper } \\
\text { Social Media }\end{array}$ & & & \\
\hline Officials & $\begin{array}{l}\text { email } \\
\text { Telephone } \\
\text { Pen \& Paper }\end{array}$ & & & \\
\hline
\end{tabular}

Main communication form underlined; hatched cells: unknown 
Table 13.4 Media ensemble and actor constellation in German schools

\begin{tabular}{|c|c|c|c|c|}
\hline From/to & Teacher & Pupils & Parents & Officials \\
\hline Teacher & $\begin{array}{l}\frac{\text { email (private) }}{\text { Pen \& paper }} \\
\text { SIS } \\
\text { LMS } \\
\text { File Sharing }\end{array}$ & $\begin{array}{l}\text { email (private) } \\
\text { Social Media } \\
\text { LMS }\end{array}$ & $\frac{\text { email (private) }}{\text { Pen \& paper }}$ & email (official) \\
\hline Pupils & $\begin{array}{l}\text { email (private) } \\
\text { Social Media } \\
\text { LMS }\end{array}$ & & & \\
\hline Parents & email (private) & & & \\
\hline Officials & Pen \& paper & & & \\
\hline
\end{tabular}

Main communication form underlined; hatched cells: unknown

and media files with selected others (course, class, special groups or school-wide). The number and variety of accounts is limited by the administrators according to the school's policy. In SIMS and LMS, depending on the visited school, grades and behavioural notes concerning the pupils are accessible by parents. Additionally, general information can be spread through the systems. Registered accounts assure that especially grades and behavioural notes are only accessible by the responsible parents. LMS allow teacher-pupil communication (both ways), including the exchange of materials, which makes them a substitute for file sharing. SIMS are the second main source for communication between teachers as they cover different areas of within-school organization (decision support, budget, grades, behaviour) with connection to the group call systems. Parents and officials get in touch with teachers mostly via email, but parents especially also use phones to contact the school or selected teachers. There is also a regular paper exchange between schools/parents and officials (Table 13.4).

The same matrix was developed for the German schools. The variety of used media is significantly lower. The most used tools are private email addresses and pen and paper. Email is used in all sender-receiver combinations. Both visited schools use a SIS for the communication purposes between teachers. SIS contain many components of the SIMS in English schools, with the exclusion of some management applications like budgeting and facility management. Only one of the two SIS includes a pupil management (grades and attendance) with a link to the state-wide pupil database. Both schools use the system for communication among teachers about everyday school life, to organize a subject or help the principal to distribute certain information and directives 
(e.g. changes in the curriculum) among the teachers. Some teachers also use an LMS to distribute information among each other. File sharing is another important means of communication, but not that relevant as in English schools. Many teachers use email to exchange files. Some network drives can only be accessed within the school network. Some teachers use cloud storage (e.g. Dropbox) for file sharing. Teachers also use social media (mainly Facebook) to communicate with pupils. The fragmentary ICT equipment in both schools may be the reason for the less intense use of LMS as they also offer the possibility to use them from home.

The two matrices show similarities and differences among the cross-national comparison. Email has a much stronger official character in England than in Germany. In Germany, non-digital media is still very widespread, especially in combination with pigeon holes. Communication in England is more mediatized and standardized.

\subsubsection{The Relation Between Communicative Practices and the School's Media Ensemble}

After mapping the actor constellation and the media ensemble into a matrix, it became clear that the cross-national differences also lead to different communicative practices. We began to find an aggregated description of communicative practices in relation to the existing media, by characterizing it as either selective or public. Public information or communication can be accessed by almost everyone. On the other hand, selective communication can only be accessed by formerly chosen receivers (teachers, pupils, groups). Additionally, it became obvious that the media ensemble affords communicative practices in different situations and for different purposes. The main differentiation was between control and monitoring and exchange and information. The former is used for school management like grades, attendance or other topics concerning pupils. The latter is information about school life, dates and other announcements. In Fig. 13.1, both the selectivity and the purposes are displayed in a coordinate system for English schools only. This allows us to map the two subjects precisely. Some media may serve multiple communicative practices and may be mapped multiple times.

Communication via social media must be split up into sub-groups. Three providers were mentioned during the group discussions. Facebook groups are mainly used for the communication between teachers and pupils. The groups establish a restricted communication area which 
is usually limited to classes or courses. The main focus is on questions about homework or class-related topics. The closed user group makes the communication selective. The other two mentioned providers are Twitter and Vine. Both services are used by teachers for sharing information with parents. Vine especially is used regularly at Beaumonde Academy. The teachers upload small videos during class trips, which allows parents at home to stay informed. Twitter is used to publish information and results. Both services are focused on the public sphere and offer information:

The first time we used it was on a (.) school trip that we run, erm it's a sports (out) sports trip (.) erm as part of (.) erm the PE department run but it's an open sports trip (.) and the initial usage of was about communicating with the parents a little bit more openly (.) so that they can see what the kids are up to, they know that we've arrived safely (.) things like that (.) and it was just a more instantaneous way of us doing it (...) I also use erm (.) an accompaniment to Twitter (.) erm is Vine (.) which is threeseco- er six-second videos (.) erm (.) and this one we use (.) this one we use to give snippets of what we're up to in the department (.) so parents and students can see little snippets of their work, of their kids' work (...) (teacher group discussion at Beaumonde Academy)

The communication and exchange within an LMS can be seen as similar as those within Facebook groups. LMS also offer testing and feedback options within internal groups. The focus is on control and monitoring. The test can be done within computer labs, at home or any other situation where pupils have access to the LMS. The feedback can be individual (selective) or public to the other members of the group. The main purpose of SIMS is to monitor pupils' performance and to control their learning process. This information is strictly selective and can usually only be accessed by the teachers, other teachers of that class and teachers in superior positions. The pupil-related data can be uploaded in an aggregated form to OFSTED and are later publicly available via the OFSTED homepage. Pupil-related data can also be accessed by parents. In cases of non-attendance or other incidents, parents can be informed via short message service (SMS) or a predefined voice message. Both communication media are strictly selective but more focused on information. The LMS of the Whitefall Secondary School also offers a login for parents to access pupils' grades and homework. 
Besides email, SIMS and LMS, groupware systems are the fourth main group that support teachers' communication. The systems offer extended collaboration detached from time and space. The main focus in schools was on communication and coordination and the main services were shared calendars and the possibility to invite other teachers and organize events. Shared calendars and the organization of events are seen more selectively than public ones (owing to restricted access) and focus on exchange and information.

File sharing between teachers and pupils is also organized via shared hard drives within the school network or by cloud storage. It is regarded as more public than selective as the access to these data may be restricted to classes, courses or groups but access may only be granted by administrators. The uploaded data has informative content. Teachers share more sensitive and selective information via SIMS and email among each other. Sensitive data between pupils and teachers (homework, tests) is handled via email or LMS. Sensitive content between teachers (grades, behaviour, etc.) is handled via SIMS, sensitive digital communication between teachers and pupils is handled via LMS and via face-to-face communication.

All the schools we visited had websites to improve their public image. As websites are public, they do not contain sensitive information. The focus is not totally public as only interested persons (e.g. parents) access the site. In the social networks Twitter and Vine, uninvolved persons may receive the information by simply clicking through tweets or videos or because someone 'retweeted' a tweet of a school account. This makes them more public than websites, although tweets and videos are sorted by an algorithm. The published OSTED data is freely available. It offers aggregated school data and is also only visited by interested persons. Nevertheless, schools use this data to promote themselves and their success (Fig. 13.2).

German schools have some similarities but are actually quite different. First, the media ensemble has fewer varieties. Second, the control and monitoring processes can be neglected. One reason might be the less reliable ICT infrastructure. But more relevant are communicative practices as well as organizational structures and policies. German teachers organize their lessons individually and independently. Only aggregated grades have to be reported at the end of the school term. During parent visits, grades might be discussed with parents. The LMS of the Bergschule includes a grade module; but only a few teachers use it regularly. The majority log on a month before the end of school term to type 


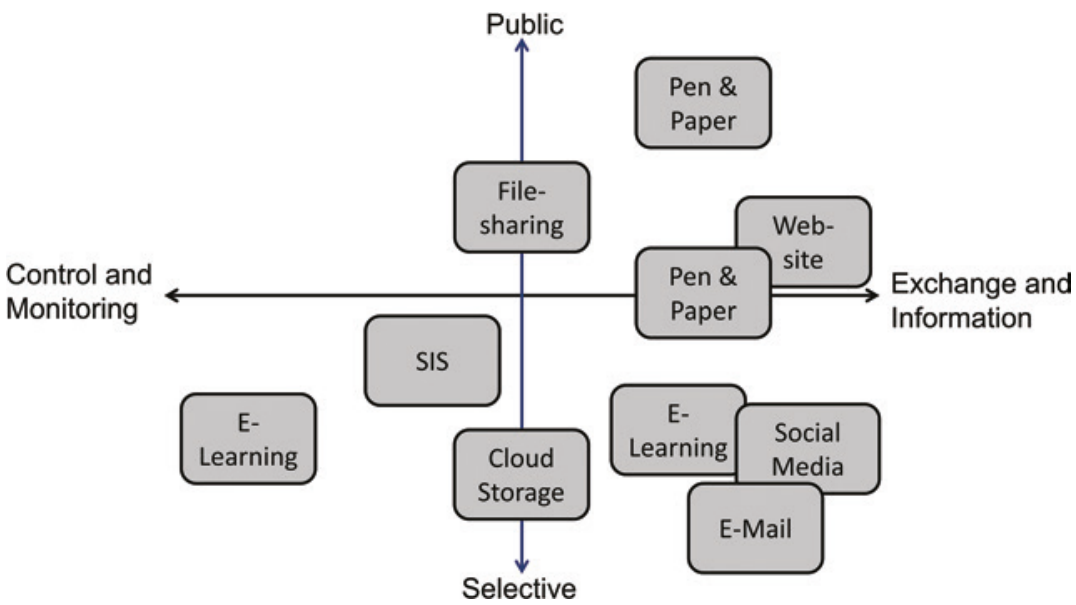

Fig. 13.2 Relation of communicative practices and media ensemble in German schools

in the final grades. Teachers do not have the possibility nor responsibility to enter data during or after each lesson as there is no computer available. Attendances and other occurrences are entered into a paper-based class register.

Paper-based communication media are used more extensively than in English schools - first because of the relevance of pigeon holes, as described above. Postal letters are still important to communicate with parents. Teachers usually do not send emails to parents but use printed letters with information about school dates (tours, parents' evenings, etc.) for the pupils to hand over at home.

Private emails and social media are used selectively and mainly for sharing information. Owing to legal constraints, the usage of private email addresses is unacknowledged, but this is sometimes the only way to reach other teachers in bigger schools. Although illegal, Facebook is used to inform pupils about urgent matters:

(...) it was about a changed date and she [other teacher, note] said, she will post that information in Facebook that all pupils can see that (.) (teacher interview at Bergschule) 
This also applies to cloud storage, which is used very selectively among smaller groups of teachers. The Waldschule uses the LMS as an official shared storage. The usability and overview of the available data is limited:

The whole thing [LMS, note] is not intuitive. - (...) it's tricky. (teacher group discussion 'Lärche' at Waldschule)

The network in the Bergschule is accessible from every computer within the school, but not from home. This hinders teachers and pupils from actively using it. In both German schools, the main fact is that the incomplete and old ICT equipment hinders a more intense usage.

The main difference between Germany and England is the more intense usage of control and monitoring purposes in English schools. SIMS fit this purpose very well. The strong focus of control and monitoring is strongly determined by the educational governance of England. In both countries, digital media allow teachers and staff to be very selective as regards who should be the receivers of their communication. This shows that choosing the right media out of the available media ensemble that relates to the communicative practices is a key competence for teachers.

\subsection{CONCLUSION}

Our empirical study in two German and three English schools show some interesting similarities as well as large differences. If we assume that the frame of relevance of any school in a state school system is to provide good education and equal opportunities, the underlying administrative processes might vary according to the governance structures. The actor constellation is similar, although administrative staff in English schools have different responsibilities compared with their German counterparts. The media environment in both countries is comparable, although there are differences in the appropriation of social media. This applies especially to the usage of Twitter, which is much more common in the UK than in Germany. Communicative practices vary significantly and especially regarding the media ensemble of the school. As we show, the core system of communication in English schools comprises management information systems such as SIMS. Although we selected schools in Germany with an existing LMS in place, the role of this medium within the media ensemble is rather low. What are the reasons for such different developments? As indicated in the beginning, the role of governance structures is often 
underestimated in the appropriation of media and its related communicative practices. There is significantly more pressure within the English system owing to decentralization and, as a necessary side effect, accountability. Management principles such as new public management are far more widespread and at the centre of the English school system than so far in Germany. There is a kind of 'data culture' that embraces school rankings and data-based decision-making and the legal framework conditions alike. In all schools, the most challenging decision for teachers is to use the best suitable communication tool in the currently given context and based on the opposite communication partner(s). All schools offer a wide media ensemble for addressing colleagues. Parents expect public data and a higher degree of transparency. This is represented in the school's media ensemble. Furthermore, the right form (formal versus informal, selective versus open) has to be chosen. This applies especially to German schools, as privacy laws and policies usually prohibit a number of mediarelated communication practices. All in all, this is reflected in different communicative figurations which construct the school as an organization.

\section{Notes}

1. Part of the DFG Priority Program 1505 "Mediatized Worlds" (funding number: BR 2273/10-1).

2. http://www.education.gov.uk/schools/performance/. Accessed: 28 May 2015.

3. http://www.education.gov.uk/schools/performance/about/index.html. Accessed: 28 May 2015.

4. http://www.legislation.gov.uk/ukpga/2010/32/contents. Accessed: 30 March 2017.

5. http://www.naace.co.uk/ictmark. Accessed: 30 March 2017.

6. http://www.naace.co.uk/about. Accessed: 30 March 2017.

7. Strickley et al. (2014) combine four measures (expected progress in maths and writing, main threshold level, average point score, value-added) into one National Single Indicator (NSI), which ranges from A to E.

\section{REFERENCES}

Academies Act 2010. 2010. http://www.legislation.gov.uk/ukpga/2010/32/ contents. Accessed 30 Mar 2017.

Altrichter, Herbert. 2010. Theory and evidence on governance: Conceptual and empirical strategies of research on governance in education. European Educational Research Journal 9 (2): 147-158. 
Anagnostopoulos, Dorothea, Stacey A. Rutledge, and Rebecca Jacobsen. 2013. The infrastructure of accountability: Data use and the transformation of American education. Cambridge, MA: Harvard Education Press.

Arnott, Margaret A., and Charles D. Raab. 2000. The governance of schooling. Comparative studies of devolved management. London and New York: Macmillan.

Avgeriou, Paris, Andreas Papasalouros, Symeon Retalis, and Manolis Skordalakis. 2003. Towards a pattern language for learning management systems. Educational Technology \& Society 6 (2): 11-24.

Ball, Stephen. 2007. Education Plc: Understanding private sector participation in public sector education. London: Routledge.

Berg, Bruce L. 2009. Qualitative research methods for the social sciences. Boston, MA: Allyn \& Bacon.

Blumberg, Arthur, and William Greenfield. 1986. The effective principal. Perspectives on school leadership. Boston, MA: Allyn \& Bacon.

Breiter, Andreas. 2001. Digitale Medien im Schulsystem: Organisatorische Einbettung in Deutschland, den USA und Großbritannien. Zeitschrift für Erziehungswissenschaft 4 (4): 625-639.

Burch, Patricia E. 2006. The new educational privatization: Educational contracting and high stakes accountability. Teachers College Record 108 (12): 2582-2610.

Cuban, Larry. 2001. Oversold and underused: Computers in classrooms. Cambridge, MA: Harvard University Press.

De Smet, C., J. Bourgonjon, B. De Wever, T. Schellens, and M. Valcke. 2012. Researching instructional use and the technology acceptation of learning management systems by secondary school teachers. Computers \& Education 58 (2): 688-696. https://doi.org/10.1016/j.compedu.2011.09.013.

DuFour, Richard. 2002. The leading-centered principal. Educational Leadership $59(8): 12-15$.

Elias, Norbert. 1978. The history of manners. The civilizing process. New York: Pantheon.

Fauske, Janice R., and Rebecca Raybold. 2005. Organizational learning theory in schools. Journal of Educational Administration 43 (1): 22-40.

Flick, Uwe. 2014. An introduction to qualitative research. London: Sage.

Fraillon, Julian, John Ainley, Wolfram Schulz, Tim Friedman, and Eveline Gebhardt. 2014. Preparing for life in a digital age. The IEA international computer and information literacy study international report. Open Access: Springer Online.

Fullan, Michael G. 2001. The new meaning of educational change, 3rd ed. New York: Teachers College Press.

Green, Reginald L. 2010. The four dimensions of principal leadership. A framework for leading 21st century schools. Boston, MA: Allyn \& Bacon. 
Grek, Sotiria. 2009. Governing by numbers: The PISA "effect" in Europe. Journal of Education Policy 24 (1): 23-37.

Hodas, Steven. 1996. Technology refusal and the organizational culture of schools. In Computerization and controversy. Value conflicts and social choice, ed. Rob Kling, 197-218. San Diego, CA: Academic Press.

Huber, Stephan G., and Bettina Gördel. 2006. Quality assurance in the German school system. European Educational Research Journal 5 (3): 196-209.

Jacobsen, Rebecca, and Tamara V. Young. 2013. The new politics of accountability: Research in retrospect and prospect. Educational Policy 27 (2): 155-169.

Karbautzki, Louisa, and Andreas Breiter. 2011. Lernplattformen im Unterricht. Organisationslücken bei der Implementierung von E-Learning in Schulen. Log In-Informatische Bildung und Computer in der Schule 169/170: 34-39.

KMK. 2005. Bildungsstandards der Kultusministerkonferenz. Bonn: Sekretariat der Ständigen Konferenz der Kultusminister der Länder in der Bundesrepublik Deutschland.

Kozma, Robert B. 2003a. ICT and educational change. A global phenomenon. In Technology, innovation, and educational change. A global perspective. $A$ report of the second information technology in education study module 2, ed. Robert B. Kozma, 1-18. Eugene, OR: International Society for Technology in Education (ISTE).

Kozma, Robert B. 2003b. Technology, innovation, and educational change. A global perspective. A report of the second information technology in education study module 2. Eugene, OR: International Society for Technology in Education (ISTE).

Leithwood, Kenneth, and Louis K. Seashore. 1998. Organizational learning in schools. Lisse: Swets and Zeitlinger.

Lijphart, Arend. 1971. Comparative politics and the comparative method. American Political Science Review 65 (3): 682-693.

Livingstone, Sonia. 2009. Children and the internet. Great expectations, challenging realities. Cambridge, MA: Polity Press.

Livingstone, Sonia, and Julian Sefton-Green. 2016. The class: Living and learning in the digital age. New York: NYU Press.

March, James G., and Johan P. Olsen. 1986. Garbage can models of decision making in organizations. In Ambiguity and command, ed. James March, and Roger Weissinger-Baylon, 11-35. Marshfield, MA: Pitman.

Martens, Kerstin, Alexander-Kenneth Nagel, Michael Windzio, and Ansgar Weymann. 2010. Transformation of education policy. Basingstoke: Palgrave.

Martens, Kerstin, Alessandra Rusconi, and Kathrin Leuze. 2007. New arenas of education governance - The impact of international organizations and markets on educational policymaking. Houndmills and Basingstoke: Palgrave.

Mayer-Schönberger, Viktor, and Kenneth Cukier. 2013. Big data: A revolution that will transform how we live, work, and think. London: John Murray. 
OECD. 2001. What works in innovation in education: New school management approaches. Paris: Organization of Economic Development and Co-operation.

Pelgrum, Willem J. 2001. Obstacles to the integration of ICT in education: Results from a world-wide educational assessment. Computers \& Education 37: 163-178.

Petko, Dominik, and Thomas Moser. 2009. Bedingungen der Nutzung von Lernplattformen in Schulen. Empirische Befunde $\mathrm{zu}$ einem nationalen Modellprojekt aus der Schweiz. Zeitschrift für E-Learning 4 (3): 20-31.

Plomp, Tjeerd, Ronald E. Anderson, Nancy Law, and Andreas Quale. 2003. Cross-national information and communication technology policies and practices in education. Greenwich, CT: Information Age Publishing.

Pollitt, Christopher, and Geert Bouckaert. 2000. Public management reform: A comparative analysis. Oxford: Oxford University Press.

Putnam, Linda, and Anne M. Nicotera. 2009. Building theories of organization: The constitutive role of communication. New York: Routledge.

Schulz, Arne H., and Andreas Breiter. 2013. Monitoring user patterns in school information systems using logfile analysis. In Next generation of information technology in educational management. 10th IFIP WG 3.7 Conference, ITEM 2012. Bremen, Germany, August 2012. Revised selected papers, ed. Don Passey, Andreas Breiter, and Adrie Visscher, 94-103. Heidelberg: Springer.

Selwyn, Neil. 2011. Schools and schooling in the digital age: A critical analysis. London: Routledge.

Selwyn, Neil. 2013. Education in a digital world: Global perspectives on technology and education. New York: Routledge.

Sergiovanni, Thomas J., Martin Burlingame, Fred S. Coombs, and P. Thurston. 1987. Educational governance and administration. Englewood Cliffs, NJ: Prentice-Hall.

Spector, J., M.David Michael, Jan Elen Merrill, and M.J. Bishop. 2014. Handbook of research on educational communications and technology. Boston, MA: Springer.

Strickley, Alan, John Bertram, Dave Chapman, Michael Hart, Roy Hicks, Derek Kennedy, and Mark Phillips. 2014. A national single indicator for schools in England: Helping parents make informed decisions. In Key competencies in ICT and informatics. Implications and issues for educational professionals and management, ed. Don Passey and Arthur Tatnall, 331-345. Berlin and Heidelberg: Springer.

Taylor, James R., and Elizabeth J. van Every. 2011. The situated organization: Case studies in the pragmatics of communication research. New York: Routledge.

Volkoff, Olga, Diane M. Strong, and Michael B. Elmes. 2007. Technological embeddedness and organizational change. Organization Science 18 (5): 832-848. 
Voogt, Joke, and Gerald Knezek. 2008. The importance of information technology attitudes and competencies in primary and secondary education. In International handbook of information technology in primary and secondary education, ed. Joke Voogt, and Gerald Knezek, 321-332. Boston, MA: Springer Science.

Weick, Karl E. 1969. The social psychology of organizing. Reading, MA: Addison Wesley.

Weick, Karl E. 1976. Educational organizations as loosely coupled systems. Administrative Science Quarterly 21: 1-19.

Weick, Karl E. 1982. Administering education in loosely coupled schools. Phi Delta Kappan 63 (10): 673-676.

Weick, Karl E., Kathleen M. Sutcliffe, and David Obstfeld. 2005. Organizing and the process of sense making. Organization Science 16 (4): 409-421.

Welling, Stefan, Andreas Breiter, and Arne H. Schulz. 2014. Mediatisierte Organisationswelten in Schulen: Wie der Medienwandel die Kommunikation in den Schulen verändert. Wiesbaden: Springer VS.

Wissinger, Jochen. 2002. Schulleitung im internationalen Vergleich-Ergebnisse der TIMSS-Schulleiterbefragung. In Schulleitungs-Forschung und-Qualifizierung, ed. Jochen Wissinger, and Stephan G. Huber, 45-61. Opladen: Leske + Budrich.

Wong, Kenneth K. 2013. Politics and governance: Evolving systems of school accountability. Educational Policy 27 (2): 410-421.

Open Access This chapter is licensed under the terms of the Creative Commons Attribution 4.0 International License (http://creativecommons.org/licenses/ by $/ 4.0 /$ ), which permits use, sharing, adaptation, distribution and reproduction in any medium or format, as long as you give appropriate credit to the original author(s) and the source, provide a link to the Creative Commons license and indicate if changes were made.

The images or other third party material in this chapter are included in the chapter's Creative Commons license, unless indicated otherwise in a credit line to the material. If material is not included in the chapter's Creative Commons license and your intended use is not permitted by statutory regulation or exceeds the permitted use, you will need to obtain permission directly from the copyright holder.

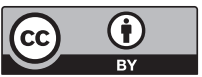

